UDC 339.972

\title{
Comparative analysis of the infrastructure basis for the transition to the digital economy of Latin America
}

\author{
Svetlana Yu. Revinova, Diana Pamela Chavarry Galvez \\ Peoples' Friendship University of Russia (RUDN University) \\ 6 Miklukho-Maklaya St., Moscow, 117198, Russian Federation
}

\begin{abstract}
In the last decade, almost all countries of the world have developed strategies for the transition to a digital economy. The introduction of digital technologies is observed in all spheres of our life: from simple household consumption to public administration. Latin American countries have not been left out of this process. However, the readiness for such a transition varies for the countries of the region. The purpose of this article is a comparative analysis of the infrastructure base of Latin American countries for the transition to a digital economy. The starting point for this transition is the provision of public access to the Internet and the ability of the population to take advantage of the opportunities provided by digital technologies. The basis for the study was the database of the World Bank, the online portal "Statista" and other open sources. Comparison and pattern matching methods were used in the process. The analysis showed that Chile, Argentina, Uruguay, Costa Rica are among the leading countries in the readiness of the infrastructure base for the transition to a digital economy. Countries lagging in this indicator - Haiti, Nicaragua, Honduras, Venezuela. It is noted that in these countries it is necessary to create new institutions, stimulate innovation. In general, the Latin American region at the moment belongs to the middle group of digitalization but has great potential and good prospects.
\end{abstract}

Keywords: digital economy, digitalization, Latin America, Internet

\section{Introduction}

Currently, the issues of transition to the digital path of economic development are coming to the fore in all countries. These changes are based on the use of information and communication technologies. The concept of the fourth industrial revolution, or "Industry 4.0", was first formulated at the Hanover exhibition in 2011, defining it as the introduction of "cyber-physical systems" into production processes. It is assumed that these systems will be combined into one network, communicate with each other in real-time, configure themselves and learn new behaviors. Such networks will be able to build a line of production with fewer errors, interact with manufactured goods and, if necessary, adapt to new consumer needs. For example, a product in the production process will be able to determine the equipment capable of producing it. And all this in a completely offline mode

(C) Revinova S.Yu., Chavarry Galvez D.P., 2019

(c) (i) This work is licensed under a Creative Commons Attribution 4.0 International License https://creativecommons.org/licenses/by/4.0/ 
without human intervention. The fourth industrial revolution has the potential to accelerate economic growth and alleviate some global problems.

Already now there is a wide introduction of tools of digital economy in production. Many services can be obtained from the comfort of home, the chain of intermediaries is reduced, a variety of data becomes a valuable resource. Big data, artificial intelligence, blockchain, Internet of things, cloud computing, intelligent information technologies are digitalization tools that contribute to the formation of an information society.

However, today there is a digital divide both between countries and within national economies: between urban and rural areas, between people with and without education, between high-and low-income populations, between men and women, etc. It is therefore essential that all countries focus on ensuring access to information and communication technologies.

Digitalization processes are taking place all over the world. In 2016, the Declaration "Digital economy: innovation, growth and social prosperity" was adopted, which in addition to OECD countries was signed by Argentina, Colombia, Costa Rica, and Ecuador. For Latin America, the transition to a digital economy is as relevant as for all countries in the world. The population of Latin America actively participates in e-Commerce, uses cryptocurrencies, etc., the use of digital technologies will allow the Latin American States to increase their competitiveness, improve the economic situation in the countries and increase the level of wellbeing of the population.

\section{Literature review}

The concept of digital economy appeared at the very end of the $20^{\text {th }}$ century. The basic principles of the digital economy were formulated by Nicolas Negronte. In 1995, he spoke about the disadvantages of classical goods (weight, raw materials, transport) and the advantages of the new economy (the lack of weight of goods, virtuality, almost unnecessary raw materials, instant global movement) (Negroponte, 2000). The digital economy implies a deep integration of information technologies with the real processes of the economy. The world development report 2016: digital dividends of the World Bank shows that information technology is becoming increasingly important in the economic development of all countries of the world without exception (Development of digital economy in Russia, 2016).

Raul Katz highlights 3 waves of digital technology development (Katz, 2017). The first wave is associated with the informatization and use of information management systems aimed at automating data processing and used for business monitoring and reporting; the spread of telecommunication technologies, such as broadband Internet access (fixed and mobile). The second wave of digital technologies involves the spread of the Internet and digital platforms (search engines, trading platforms). Also, the use of the Internet has led to the spread of cloud computing. The third wave of digital technologies, which began around 2010 and became the point for the formation of the digital economy and the fourth industrial revolution. At this stage, it is expected to translate the routine tasks of enterprises and governments on a digital basis. These include big data analytics, the Internet of things, robotics, adaptive technologies, and artificial intelligence. These technolo- 
gies associated with Industry 4.0 are not possible without going through the first two stages.

The author of the concept of the fourth industrial revolution, Klaus Schwab, notes that the fourth industrial revolution equally creates both huge advantages and huge problems. Growing inequality is of particular concern in society (Schwab, 2018). As compared to developed countries, in which the process of formation of Industry 4.0 was started earlier and aimed at marketing and social results, developing countries face institutional, financial barriers and seek economic goals (Bogoviz et al., 2019). The growth of digital technologies is changing the existing economic system in all developed countries with traditional processes of production and consumption. Nowadays digital technologies create another reality for governments, people, enterprises, organizations, global markets and provide a new promising growth path for any country (Khalimon et al., 2018).

The introduction of the digital economy is a lever for the development of the economic structure and the environment as a whole. The issue of formation and development of the digital economy is relevant not only from the point of view of theory, but also from the point of view of practice, including at the state level there is an understanding of the crucial role of digital technologies in the formation of the strategic competitiveness of the country (Lazanyuk et al., 2018).

In terms of technology, the Latin American region remains phase lagging behind traditional centers. But even here the advanced group of the region has its breakthrough achievements, which are due to overcoming the alienation of the sphere of research and development from the real sector of the economy and the transition to innovative practices (Davydov, 2016). The analysis of the region's position in the global innovation process shows its untapped and untapped opportunities. Innovation activity in many Latin American and Caribbean countries was below the expected level. Ratings of the three largest Latin American States - Brazil, Mexico and Argentina - fell in the XXI century. Significantly below the average for the region. At the same time, Costa Rica, Chile, as well as Trinidad and Tobago occupy higher positions (Simonova, 2016). Currently, Latin American countries are far from leading in terms of the main factors and indicators of innovative construction, even when compared with other rapidly developing economies. Their weaknesses are the lack of efficiency of production processes, extensive use of resources, a narrow range of areas of application of intellectual potential (Simonova, 2013). Studies of A.V. Bobrovnikov, E.G. Ermoliev, A.A. Lavut, L.B. Nikolaeva, V.L. Semenova, L.N. Simonova, V.M. Tayar, N.N. Kholodkova, A.V. Shcherbakova, M.V. Yanushpolskaya, N.V. Volobueva are devoted to the identification of problems and conflicts faced by the region of Latin America and the Caribbean on the way of building an innovative Economy (Simonova, 2017). The importance of the digital economy for Latin America is quite great, as Latin America is about to begin its third century of political autonomy, the digital revolution offers a new opportunity to articulate that leeway and implement alternative strategies (Gutierrez, 2004). Nevertheless, digitalization in the countries of the region is uneven. The digital divide between the countries of the region is largely dependent on broadband network access and infrastructure investment (Katz et al., 2018). Further digitalization of Latin America depends on the existing infrastructure base, investments in it and public policy. 


\section{Methodology}

The basis for the study were the works of Russian and foreign authors. The authors used methods of comparison, statistical and logical analysis. For comparative analysis and comparison, socio-economic indicators were taken from the databases of the World Bank, the Internet portal Statista and other open sources. When formulating conclusions, the method of generalization was used.

\section{Results}

Latin America is a dynamic region. Active Internet users make up 68\% of the region's population, which is higher than the global average (Internet World Stats, 2019). Latin American countries are actively involved in global digitalization processes. At the same time, there is a lag behind developed countries, which can be explained by the reluctance of the population, business and the state to implement changes.

Speaking about the countries of Latin America we mean more than 20 countries, quite different in their economic development. Thus, in terms of GDP, the top five countries in Latin America are Brazil, Mexico, Argentina, Colombia, Chile. The last line is occupied by Belize, before Belize are located Grenada, Guyana, Haiti, Nicaragua. The highest GDP per capita is observed in Puerto Rico, Peru, and the worst figure is in Venezuela (World Bank, 2019). It should be noted that there is a huge difference between the first and the last countries.

Today, the countries of the world compete with each other, and leadership in competitiveness becomes the goal of many governments. The world economic forum defines national competitiveness as the ability of a country and its institutions to achieve stable economic growth rates that would be sustainable in the medium term. The world economic forum annually presents the ranking of countries on the global competitiveness Index (The Global Competitiveness Index, 2018). The authors of the study emphasize that countries with high indicators of national competitiveness seek to ensure a higher level of well-being of their citizens. It is envisaged that the Index should be used by the governments that seek to eliminate obstacles to economic development and competitiveness as a tool to analyze the problems in their economic policies and to develop strategies for achieving sustainable economic progress. The positions of Latin American countries are not too high (Table 1).

The data presented shows that Latin American countries need to do a lot of work to achieve acceptable results. The best country on the competitiveness index, Chile, is only $33^{\text {rd }}$, and major economies such as Brazil and Argentina are not even in the first half of the list. Countries such as Haiti and Venezuela lag behind the leader by about 100 positions, which once again testifies to the existing rather strong inequality of countries.

As mentioned above, the transition to a digital economy will allow countries to improve their economic development and strengthen their competitiveness. Such a transition requires a set of factors based on a well-developed infrastructure and competencies for working with digital technologies. The spread of information technology is also uneven throughout the world. The position of Latin America on this issue is also not good enough. 
The Global Competitiveness Index, 2016-2018

Table 1

Rank of 140 countries, Rank of 137 countries, Rank of 137 countries, 2018* 2017-2018** 2016-2017***

\begin{tabular}{lccc}
\hline 1. Chile & 33 & 33 & 33 \\
2. Mexico & 46 & 51 & 51 \\
3. Uruguay & 53 & 76 & 73 \\
4. Costa Rica & 55 & 47 & 54 \\
5. Colombia & 60 & 66 & 61 \\
6. Peru & 63 & 72 & 76 \\
7. Panama & 64 & 50 & 42 \\
8. Brazil & 72 & 80 & 81 \\
9.Trinidad and Tobago & 78 & 83 & 94 \\
10. Jamaica & 79 & 70 & 75 \\
11. Argentina & 81 & 92 & 104 \\
12. Dominican Republic & 82 & 104 & 92 \\
13. Ecuador & 86 & 97 & 91 \\
14. Paraguay & 95 & 112 & 117 \\
15. Guatemala & 96 & 84 & 78 \\
16. El Salvador & 98 & 109 & 105 \\
17. Honduras & 101 & 96 & 88 \\
18. Nicaragua & 104 & 93 & 103 \\
19. Bolivia & 105 & - & - \\
20. Venezuela, RB & 127 & 127 & 130 \\
21. Haiti & 138 & - & - \\
\hline
\end{tabular}

Source: compiled by authors based on World Economic Forum:

* - https://www.weforum.org/reports/the-global-competitveness-report-2018 (accessed: 16.10.2018); 26.09.2017);

** - https://www.weforum.org/reports/the-global-competitveness-report-2017-2018 (accessed: 28.09.2016).

*** - https://www.weforum.org/reports/the-global-competitveness-report-2016-2017 (accessed:

The economic intelligence unit has prepared a rating of technological readiness of some countries. A total of 82 countries were surveyed. The main criterion for assessing technological readiness in this assessment is access to the Internet.

List by technical readiness in Latin America, 2018-2022

\begin{tabular}{|c|c|c|}
\hline Country & Rank & Score $(1-10)$ \\
\hline 1. Argentina & 32 & 7.18 \\
\hline 2. Chile & 36 & 6.90 \\
\hline 3. Costa Rica & 42 & 6.34 \\
\hline 4. Brazil & 47 & 6.06 \\
\hline 5. Mexico & 49 & 5.78 \\
\hline 6. Colombia & 55 & 5.50 \\
\hline 7. Ecuador & 69 & 3.81 \\
\hline 8. Peru & 69 & 3.81 \\
\hline 9. El Salvador & 71 & 3.53 \\
\hline 10. Cuba & 74 & 3.25 \\
\hline 11. Dominican Republic & 76 & 2.96 \\
\hline 12. Venezuela & 77 & 2.68 \\
\hline
\end{tabular}

Source: compiled by authors based on The Economist Intelligence Unit. https://www.eiu.com/industry/ article/516891235/technological-readiness-struggling-to-get-ahead/2018-06-29 (accessed: 27.07.2018). 
Number of internet users in selected Latin American countries as of January 2019 (in millions)

\begin{tabular}{lc}
\hline 1. Brazil & 149,1 \\
2. Mexico & 88 \\
3. Argentina & 41,59 \\
4. Colombia & 34 \\
5. Peru & 24 \\
6. Venezuela & 19,55 \\
7. Chile & 15,04 \\
8. Ecuador & 13,48 \\
9. Bolivia & 8,82 \\
10. Guatemala & 7,8 \\
11. Dominican Republic & 7,1 \\
12. Paraguay & 6,18 \\
13. Costa Rica & 4,3 \\
14. El Salvador & 3,8 \\
15. Honduras & 3,8 \\
16. Uruguay & 3,06 \\
17. Nicaragua & 2,9 \\
18. Panama & 2,9 \\
19. Haiti & 2,0 \\
20. Jamaica & 1,6 \\
21. Trinidad and Tobago & 1,01 \\
\hline
\end{tabular}

Source: compiled by authors based on Statista.com and www.internetworldstats.com (accessed: 05.08.2019).

The data presented in Table 2 show that the best in this ranking among Latin American countries were Argentina and Chile, in fact, only these 2 countries were able to get into the first half of the ranking. Of the 12 countries surveyed in the region, 4 were in the last ten.

The formation of digital economy is impossible without the adjusted infrastructure of information technologies and, first of all, access of the population to the Internet. Internet users from Latin America and the Caribbean make up 10\% of all Internet users (Internet World Stats, 2019). The largest number of Internet users is concentrated in the largest countries of the region - Brazil, Mexico, Argentina, Colombia and Peru (Table 3), which is explained by the demographics of these countries.

More indicative is the penetration of the Internet into the country, that is, the proportion of Internet users from the population of the country. The average for the study region is $65 \%$ as of June 30, 2019. The leader is Argentina, the other countries leading in the number of Internet users are in the middle of the ranking (Figure 1).

Data show that just over half of the region's population has access to the Internet and this is due to poor infrastructure, although the situation is changing quite rapidly. Households' access to the Internet is mainly provided in two ways: via broadband or mobile communication via smartphones, tablets, and mobile phones. Broadband access is the most convenient and fastest way to connect to the network, but at the same time requires some investment and support from the state. In 2018, the largest number of broadband Internet users live in Uruguay and Argentina, the smallest in Honduras and Nicaragua (Figure 2). 


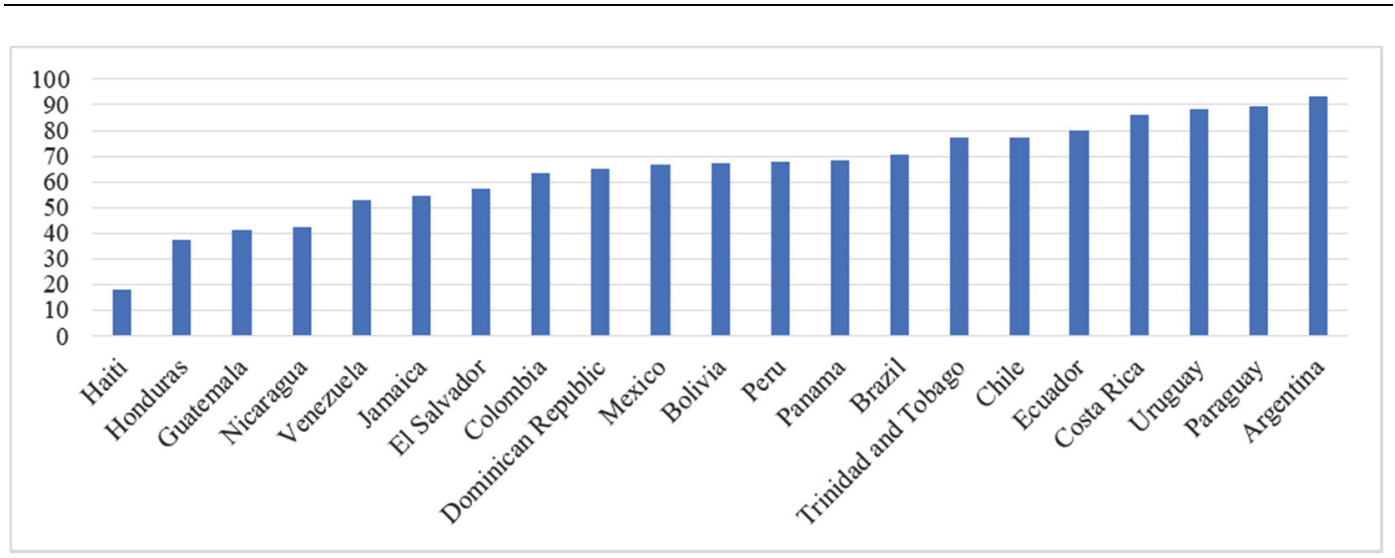

Figure1. Latin America - internet penetration 2019, by countries and percentages

Source: built by authors based on www.internetworldstats.com. (accessed: 30.06.2019).

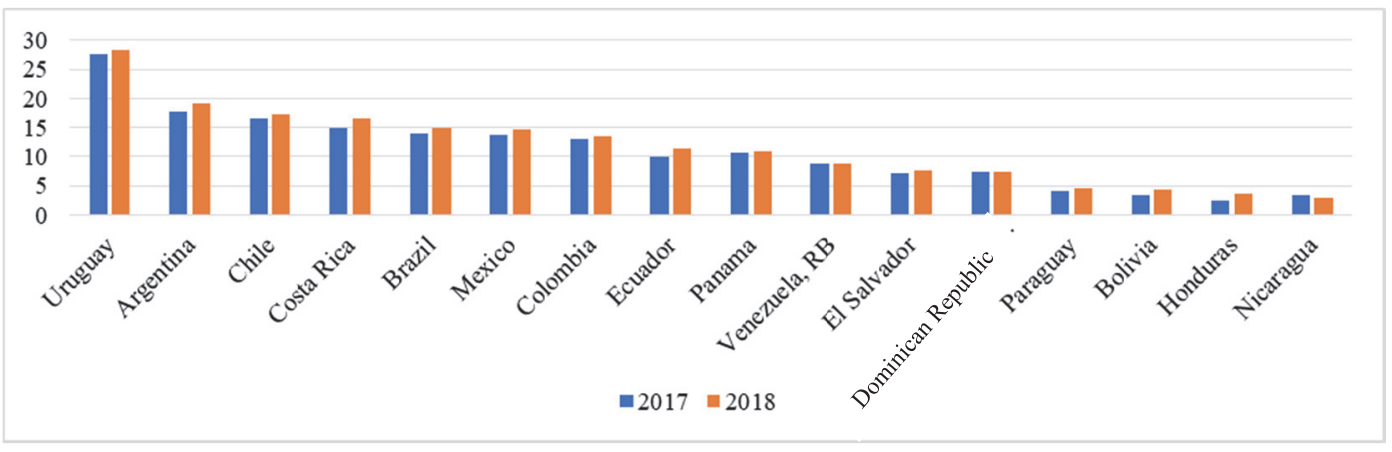

Figure 2. Fixed broadband subscription (per 100 people)

Source: built by authors based on the World Bank.

Broadband quality is also important. For example, the average download speed of broadband Internet in Uruguay is $9.16 \mathrm{Mbit} / \mathrm{s}$, Colombia - 3.48 Mbit/s, Nicaragua - 2.54 Mbit/s, Venezuela - 1.37 Mbit/s (Statista, 2018). Thus, Uruguay has the best infrastructure to use the Internet. The alternative to access the Internet today is mobile communication, which is spreading very quickly. In 2017, mobile Internet penetration in Latin America was estimated at 50\%, and it is estimated that this figure will reach $66 \%$ by 2025 . Costa Rica is the leader in terms of mobile usage (Figure 3 ).

The top five changed slightly compared to broadband users, with Brazil dropping out and El Salvador emerging.

The data allow us to identify the leading countries in terms of access to the Internet, and, accordingly, to the consumption of services provided by the digital economy. These are Argentina, Uruguay, Costa Rica, and Chile. The countries lagging behind in this indicator are Nicaragua, Honduras, Venezuela, Bolivia. The relatively high rates of mobile use in countries such as Nicaragua and El Salvador suggest that the number of Internet users in these countries will also increase. In general, we can expect an increase in the use of the network throughout the region at the expense of the younger generation. If now, the penetration of mobile Internet in Latin America is estimated at $50 \%$, then according to forecasts by 2025, this figure will grow to 66\% (Internet Usage in Latin America, 2018). 


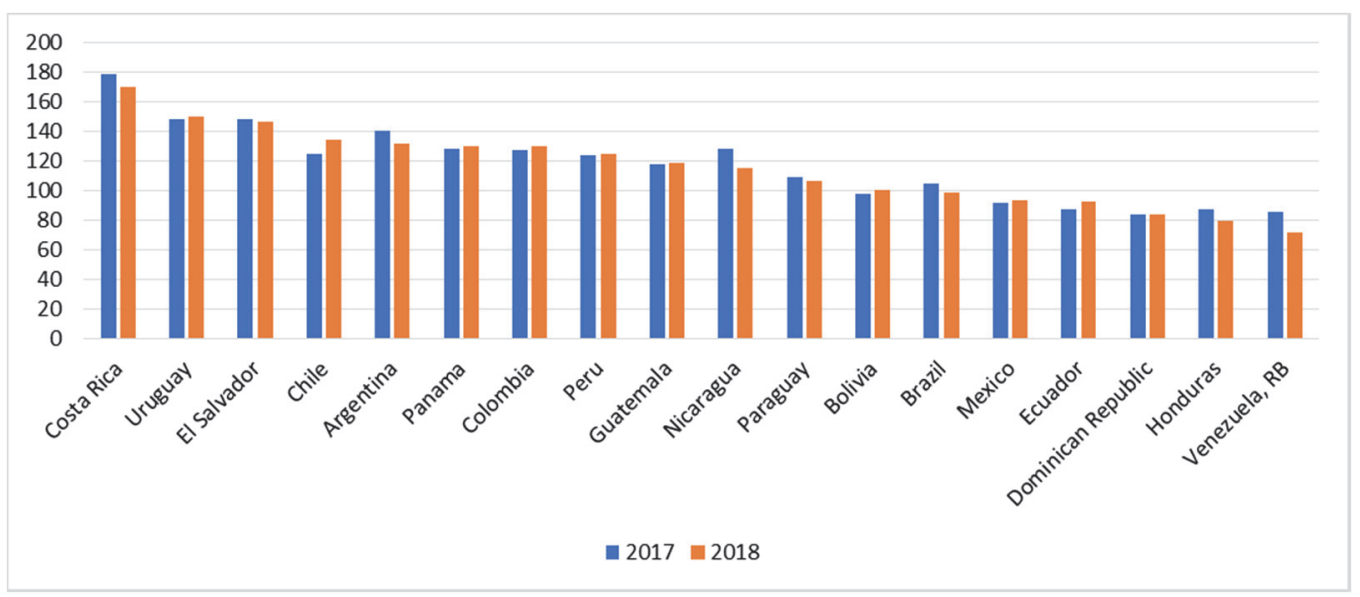

Figure 3. Mobile cellular subscriptions (per 100 people)

Source: built by authors based on the World Bank. https://data.worldbank.org/ (accessed: 29.10.2018)

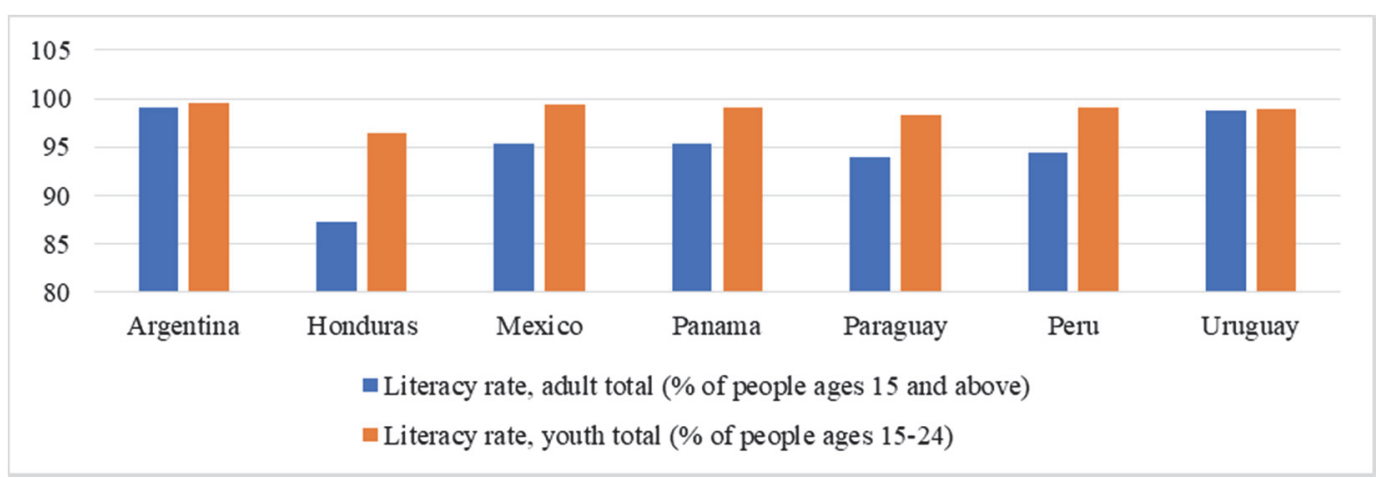

Figure 4. Literacy rate in selected countries in Latin America, 2018

Source: built by authors based on the World Bank. https://data.worldbank.org/ (accessed: 15.11.2018).

For the transition to digital development is not enough to have personal computers and the Internet, you need to understand whether the public was willing to use the opportunities provided by broadband access and mobile communication, has a population of digital skills and competencies whether it would be able to fully use new opportunities and to consume digital services.

According to the online portal "Statista", the share of Internet users among children in Latin America is very high: in Brazil - 98\%, Chile - 96\%, Argentina $92 \%$, Ecuador $-90 \%$, Peru $-84 \%$, Mexico - 83\%. Thus, it can be argued that the younger generation of Latin America behaves more freely in the Internet environment, which will undoubtedly give results in the coming years. In terms of general literacy, it is also higher among the population aged 15 to 24 (Figure 4).

At the same time, the difference between adult and young generation literacy in Uruguay and Argentina is almost imperceptible in contrast to Honduras, Peru, etc. In general, the literacy of the population in the countries of the Latin American region also differs. While in Uruguay the figure is $99 \%$ for the entire population, in Honduras only $87 \%$ of the adult population and $96 \%$ of the young population are literate. 
One of the estimates that allow us to assess the overall level of development of the country's population is the human development index, presented in the report "Human development indices and indicators: Updated statistics 2018", prepared by the United Nations Development Programme of the United Nations (Human development indices and indicators, 2018). One of the indicators taken into account in the compilation of the final index of countries - achievements in education (Table 4).

Table 4

The human development index and an indicator of "Achievements in education" in Latin America

\begin{tabular}{|c|c|c|c|c|c|c|c|c|}
\hline \multirow{4}{*}{$\begin{array}{l}\text { Index of } \\
\text { human } \\
\text { develop- } \\
\text { ment }\end{array}$} & \multirow{4}{*}{$\begin{array}{l}\text { Latin America } \\
\text { and } \\
\text { the Caribbean }\end{array}$} & \multicolumn{3}{|c|}{ Alphabetization rate } & \multirow{2}{*}{$\begin{array}{c}\text { Population } \\
\text { with at least } \\
\text { secondary } \\
\text { education } \\
\text { (\% of persons } \\
\text { aged } 25 \\
\text { and over) }\end{array}$} & \multicolumn{2}{|c|}{$\begin{array}{l}\text { Gross enrollment } \\
\text { ratio }\end{array}$} & \multirow{2}{*}{$\begin{array}{c}\begin{array}{c}\text { Public } \\
\text { spending } \\
\text { on edu- } \\
\text { cation }\end{array} \\
(\% G D P)\end{array}$} \\
\hline & & $\begin{array}{l}\text { Adult popu- } \\
\text { lation (\% of } \\
\text { people aged } \\
15 \text { and over) }\end{array}$ & $\begin{array}{r}\text { Yout } \\
\text { (\% of pe } \\
\text { aged } 15 \\
2006-2\end{array}$ & $\begin{array}{l}h \\
\text { ople } \\
-24), \\
017\end{array}$ & & $\begin{array}{c}\text { Average } \\
(\%)\end{array}$ & $\begin{array}{c}\text { Highest } \\
(\%)\end{array}$ & \\
\hline & & $2006-2016$ & Women & Men & $2006-2017$ & \multicolumn{2}{|c|}{ 2012-2017 2012-2017 } & 2012-2017 \\
\hline & & 92,8 & 98,3 & 98 & 59,6 & 96 & 49 & 5,5 \\
\hline \multicolumn{9}{|c|}{ Countries with a very high level of human development } \\
\hline 44 & Chile & 96,3 & 99,1 & 99 & 80,6 & 100 & 90 & 4,9 \\
\hline 47 & Argentina & 98,1 & 99,5 & 99,1 & 64,8 & 107 & 86 & 5,9 \\
\hline 55 & Uruguay & 98,5 & 99,2 & 98,6 & 54,1 & 112 & 56 & \\
\hline 63 & Costa Rica & 97,4 & 99,3 & 99 & 52,9 & 126 & 54 & 7,1 \\
\hline 66 & Panama & 94,1 & 97,3 & 97,9 & 71,2 & 76 & 47 & - \\
\hline 69 & $\begin{array}{c}\text { Trinidad } \\
\text { and Tobago }\end{array}$ & - & - & - & 73,4 & - & - & - \\
\hline 74 & Mexico & 94,5 & 99 & 98,9 & 59,3 & 97 & 37 & 5,3 \\
\hline 78 & Venezuela & 97,1 & 99,1 & 98,4 & 69,2 & 86 & - & - \\
\hline 79 & Brazil & 91,7 & 99,3 & 98,4 & 60 & 100 & 51 & 5,9 \\
\hline 86 & Ecuador & 94,4 & 99,1 & 99 & 52,2 & 107 & 46 & 5 \\
\hline 89 & Peru & 94,2 & 98,7 & 99,1 & 62,2 & 98 & - & 3,8 \\
\hline 90 & Colombia & 94,2 & 98,9 & 98,2 & 50,2 & 98 & 59 & 4,5 \\
\hline 94 & $\begin{array}{l}\text { Dominican } \\
\text { Republic }\end{array}$ & 92 & 98 & 97,2 & 56,6 & 77 & 53 & - \\
\hline 97 & Jamaica & - & - & - & 66,3 & 84 & 27 & 5,4 \\
\hline 106 & Belize & - & - & - & 78,6 & 87 & 24 & 7,4 \\
\hline 110 & Paraguay & 95,1 & 98,6 & 98 & 48 & 77 & - & 5 \\
\hline \multicolumn{9}{|c|}{ Countries with an average level of human development } \\
\hline 118 & Bolivia & 92,5 & 99,4 & 99,4 & 58,2 & 86 & - & 7,3 \\
\hline 121 & El Salvador & 88 & 98,4 & 97,5 & 43,3 & 74 & 28 & 3,5 \\
\hline 124 & Nicaragua & - & - & - & 47,5 & - & - & - \\
\hline 127 & Guatemala & 81,3 & 93,3 & 95,5 & 37,8 & 64 & 21 & 2,8 \\
\hline 133 & Honduras & 89 & 97,2 & 94,9 & 35,5 & 65 & 20 & 5,9 \\
\hline 168 & Haiti & 48,7 & 70,5 & 74,4 & - & - & - & - \\
\hline
\end{tabular}

Source: compiled by authors based on http://hdr.undp.org/sites/default/files/2018_human_ development_statistical_update_ru.pdf (accessed: 29.06.2018).

In this report, countries are divided into three main groups according to the human development index. Most Latin American countries belong to the group of 
countries with a high level of human development and six countries to the group with an average level.

It should be noted that in Latin America and the Caribbean, less than half of the population has higher education. Chile has the best indicator, followed by Argentina, Colombia, Uruguay. The lowest proportion of the population with higher education in Haiti, Honduras, Guatemala. These countries need to take measures to improve the overall level of education, without qualified personnel with skills to work with digital technologies it is impossible to catch up with more developed countries and join the competition.

\section{Conclusion}

The Latin American region has enormous potential for digital growth, but it is currently in the middle of digitalization worldwide. There is great economic inequality both between the countries of the region and within the countries.

The population has unequal access to information technology, due to poor infrastructure, low broadband and mobile connectivity, and an underdeveloped institutional environment. Also, some countries have low levels of literacy, which automatically reduces the potential of the digital economy. The population simply cannot take advantage of the services provided due to the lack of skills and qualifications to work with them.

Chile, Argentina, Uruguay, and Costa Rica are among the leading countries in terms of readiness of the infrastructure basis for the transition to the digital economy. The countries lagging in this indicator are Haiti, Nicaragua, Honduras, Venezuela. Lagging countries need to create new institutions, stimulate innovation. The most reliable way to increase the dynamics of development for them will be to improve public access to the Internet through the use of mobile Internet.

Although access to the network has improved over the years, a large number of people in the region remain disconnected or under-connected and, as a result, are not covered by already widespread services such as e-banking, e-Commerce, public services, e-health, etc. However, it should be noted that the situation in many developing countries is changing very quickly, the spread of information technology cannot be stopped. The population is rapidly becoming involved in digital processes, which determines good prospects for the Latin American region.

\section{References}

Bogoviz, A.V., Osipov, V.S., Chistyakova, M.K., \& Borisov, M.Y. (2019). Comparative analysis of formation of Industry 4.0 in developed and developing countries. Studies in Systems, Decision and Control, 169, 155-164. Springer International Publishing. Retrieved from https://doi.org/10.1007/978-3-319-94310-7_15 (accessed: 22.07.2018).

Davydov, V.M. (2016). Determination of the development of Latin-Caribbean America. Integration of global and regional issues. Moscow: ILA RAS.

The World Bank Open Knowledge Repository. (2016). Development of digital economy in Russia. Report. Retrieved from https://openknowledge.worldbank.org/ (accessed: 20.12.2016).

Gutierrez, M.A. (2004). Latin America and the digital economy challenge. Foresight. Retrieved from https://doi.org/10.1108/14636680410547762 (accessed: 01.06.2014). 
Human Development Report. (2018). Human development indices and indicators - 2018. Updated static data. Retrieved from http:/hdr.undp.org/sites/default/files/2018_human_ development_statistical_update_ru.pdf(accessed: 29.06.2018).

Statista. (2018). Internet Usage in Latin America. Retrieved from http://www.statista.com (accessed: 05.08.2019).

Internet World Stats. (2018). Internet Usage in Latin America. Retrieved from https:// www.internetworldstats.com/stats.htm (accessed: 16.10.2018).

Internet World Stats. (2018). Retrieved from https://www.internetworldstats.com/stats.htm (accessed: 30.06.2018).

Katz, R. (2017). Social and economic impact of digital transformation on the economy. ITU, GSR-17. Discussion paper. Retrieved from https://www.itu.int/en/ITU-D/Conferences/ GSR/Documents/GSR2017/Soc_Eco_impact_Digital_transformation_finalGSR.pdf) (accessed: 30.07.2017).

Katz, R., \& Callorda, F. (2018). Accelerating the development of Latin American digital ecosystem and implications for broadband policy. Telecommunications Policy, 42(9), 661-681. Retrieved from https://doi.org/10.1016/j.telpol.2017.11.002 (accessed: 29.06.2018).

Khalimon, A., Guseva, M.N., Kogotkova, I.Z., \& Brikoshina I.S. (2018). Digitalization of the Russian Economy: First Results. The European Proceedings of Social \& Behavioural Sciences EpSBS, LVII - GCPMED 2018 (21), 199-213 doi: https://dx.doi.org/10.15405/ epsbs.2019.03.21

Lazanyuk, I., Revinova, S., Balashova, S., \& Volgina, N. (2018). It Industry as A Prerequisite for Digital Economy (Cases of Russia and India). $5^{\text {th }}$ International Multidisciplinary Scientific Conference on Social Sciences and Arts SGEM2018 (24 August - 2 September 2018): Conference Proceedings, 5(1.3), 647-654. doi: 10.5593/SGEMSOCIAL2018/1.3.

Negroponte, N. (2000). Being digital. New York: Knopf.

Simonova, L.N. (2013). Latin America on the path of economic modernization. Moscow: ILA RAS.

Simonova, L.N. (2016). Innovation policy of Latin America: trends and problems (round table in ILA RAS). Latin America, (3), 76-91.

Simonova, L.N. (2017). Opportunities and limits of innovative development of Latin America. Moscow: ILA RAS Publ.

Statista. (2019). Retrieved from https://www.statista.com/ (accessed: 05.08.2019).

Schwab, K. (2019). The Fourth Industrial Revolution. Retrieved 26 June 2019 from https:// www.weforum.org/about/the-fourth-industrial-revolution-by-klaus-schwab

The World Economic Forum. (2016). The Global Competitiveness Report 2016-2017. Retrieved from https://www.weforum.org/reports/the-global-competitveness-report-20162017 (accessed: 28.09.2016).

The World Economic Forum. (2017). The Global Competitiveness Report 2017. Retrieved from https://www.weforum.org/reports/the-global-competitveness-report-2017-2018 (accessed: 26.09.2017).

The World Economic Forum. (2018). The Global Competitiveness Report 2018. Retrieved from https://www.weforum.org/reports/the-global-competitveness-report-2018 (accessed: 16.10.2018).

World Bank data. (2018). Retrieved from https://data.worldbank.org/ (accessed: 29.11.2018).

\section{Article history:}

Received: 15 September 2019

Revised: 30 October 2019

Accepted: 22 November 2019

\section{For citation:}

Revinova, S.Yu., \& Chavarry Galvez, D.P. (2019). Comparative analysis of the infrastructure basis for the transition to the digital economy of Latin America. RUDN Journal of Economics, 27(4), 761-773. http://dx.doi.org/10.22363/2313-2329-2019-27-4-761-773 


\title{
Bio notes:
}

Svetlana Yu. Revinova, Ph.D., Associate Professor of the Department of Economic and Mathematical Modeling, Peoples' Friendship University of Russia (RUDN University). E-mail: revinova_syu@pfur.ru

Diana Pamela Chavarry Galvez, Ph.D. student of the Department of Economic and Mathematical Modeling, Peoples' Friendship University of Russia (RUDN University). E-mail: diana_p48@hotmail.com

Научная статья

\section{Сравнительный анализ инфраструктурного базиса для перехода к цифровой экономике стран Латинской Америки}

\author{
С.Ю. Ревинова, Д.П. Чаварри Гальвес
}

Российский университет дружбы народов Российская Федераџия, 117198, Москва, ул. Миклухо-Маклая, 6

В последнее десятилетие практически все страны мира разработали стратегии для перехода к цифровой экономике. Внедрение цифровых технологий наблюдается во всех сферах жизни, начиная от простого потребления домохозяйств, заканчивая государственным управлением. Страны Латинской Америки не остались в стороне от этого процесса. Тем не менее готовность к этому переходу неравномерна для стран региона. Целью данной статьи является сравнительный анализ инфраструктурного базиса стран Латинской Америки для перехода к цифровой экономики. Основой для такого перехода является обеспечение доступа населения к сети Интернет и способность населения использовать возможности, предоставляемые цифровыми технологиями. Основной для исследования послужили базы данных Всемирного банка, онлайн-портала Statista и другие открытые источники. В процессе работы использовались методы сравнения и сопоставления. Проведенный анализ показал, что к группе стран - лидеров по готовности инфраструктурного базиса для перехода к цифровой экономике относятся Чили, Аргентина, Уругвай, Коста-Рика. К отстающим по этому показателю странам относятся Гаити, Никарагуа, Гондурас, Венесуэла. Отмечается, что этим странам нужно создавать новые институты, стимулировать внедрение инноваций. В целом регион Латинской Америки относится к средней группе цифровизации на данный момент, но имеет большой потенциал и хорошие перспективы. тернет

Ключевые слова: цифровая экономика, цифровизация, Латинская Америка, ин-

\section{История статьи:}

Дата поступления в редакцию: 15 сентября 2019

Дата проверки: 30 октября 2019

Дата принятия к печати: 22 ноября 2019

\section{Для цитирования:}

Revinova S.Yu., Chavarry Galvez D.P. Comparative analysis of the infrastructure basis for the transition to the digital economy of Latin America (Сравнительный анализ инфра- 
структурного базиса для перехода к цифровой экономике стран Латинской Америки) // Вестник Российского университета дружбы народов. Серия: Экономика. 2019. T. 27. № 4. C. 761-773. http://dx.doi.org/10.22363/2313-2329-2019-27-4-761-773

\section{Сведения об авторах:}

Ревинова Светлана Юрьевна, кандидат экономических наук, доцент кафедры экономико-математического моделирования, Российский университет дружбы народов. E-mail: revinova_syu@pfur.ru

Чаварри Гальвес Диана Памела, аспирант кафедры экономико-математического моделирования, Российский университет дружбы народов. E-mail: diana_p48@hotmail.com 